\title{
Sildenafil citrate on retrobulbar and retinal circulation of rabbits
}

\author{
Citrato de sildenafil sobre a circulação retrobulbar e retiniana de coelhos
}

\author{
Andréia Vitor Couto do Amaral ${ }^{I}$ Germana Alegro da Silva ${ }^{\mathrm{II}}$ Ana Paula Araújo Costa ${ }^{\mathrm{III}}$ \\ Cássia Maria Molinaro Coelho ${ }^{\mathrm{II}}$ Roberta Renzo ${ }^{\mathrm{II}}$ José Luiz Laus ${ }^{\mathrm{II}}$
}

\section{ABSTRACT}

The effects of sildenafil on retrobulbar and retinal circulation were studied in 18 adult male, albino, homozygous rabbits, of the New Zealand White breed, randomly divided into 3 groups of 6 animals, for drug treatment at a dose of $3.5 \mathrm{mg} \mathrm{kg}^{-1}$ every 24 hours, for 7, 15 and 30 days. Nine animals used for control were treated with saline solution at $0.9 \%$. It was evaluated intraocular pressure (IOP), mean arterial pressure (MAP), ocular perfusion pressure (PPO), B-mode ultrasonography and fluorescein angiography before and at the end of treatments. A slight decrease in results of IOP, MAP and PPO after treatment with sildenafil was evident, however, there was no statistical significance. It was observed significant increased diameter of the ophthalmic artery after 7 and 30 days of treatment and decreased mean arterial pressure after 7, 15 and 30 days of treatment, with no statistical difference. On fluorescein angiography, it was observed that the arterial, arteriovenous and venous stages initiated more rapidly in animals after treatment, with significant difference on the arteriovenous stage at the $7^{\text {th }}$ and $15^{\text {th }}$ days. It was possible to admit that the sildenafil citrate improves blood circulation in the retina of rabbits, by increasing the speed of blood flow and decreasing the perfusion pressure.

Key words: rabbits, sildenafil citrate, retrobulbar circulation, retinal circulation, ultrasonography, fluorescein angiography.

\section{RESUMO}

Os efeitos do sildenafil sobre a circulação retrobulbar e a retiniana foram estudados em 18 coelhos machos adultos, albinos, homozigotos, da raça Nova Zelândia Branco, distribuídos aleatoriamente em 3 grupos de 6 animais, para tratamento com o fármaco na dose de 3,5 $\mathrm{mg} \mathrm{kg}^{-1}$ a cada 24 horas, por 7, 15 e 30 dias. Nove animais foram utilizados para controle, tratados com solução fisiológica a 0.9\%. Foram avaliadas a pressão intraocular (PIO), a pressão arterial média (PAM) e a pressão de perfusão ocular (PPO), ultrassonografia em modo-B e a angiografia fluoresceínica, antes e ao término dos tratamentos. Evidenciouse discreta diminuição nos resultados da PIO, da PAM e da PPO após tratamento com sildenafil, entretanto não houve significância estatística. Observou-se aumento significativo do diâmetro da artéria oftálmica após 7 e 30 dias de tratamento e diminuição da pressão arterial média após 7, 15 e 30 dias de tratamento, sem diferença estatística. À angiografia fluoresceínica, observouse que as fases arterial, artério-venosa e venosa iniciaram-se mais rapidamente nos animais após o tratamento, com diferença significativa na fase artério-venosa ao $7^{\circ}$ e $15^{\circ}$ dias. Foi possível admitir que o citrato de sildenafil melhora a circulação de sangue na retina de coelhos, através do aumento da velocidade do fluxo de sangue e diminuição da pressão de perfusão. $\begin{array}{ll}\text { Palavras-chave: } & \begin{array}{l}\text { coelhos, citrato de sildenafil, circulação } \\ \text { retrobulbar, }\end{array} \\ & \text { circulação } \\ \text { retiniana, }\end{array}$ ultrassonografia, angiografia fluoresceínica.

\section{INTRODUCTION}

The action of phosphodiesterase type 5 inhibitor drug in the treatment of erectile dysfunction is recognized. One of its representatives, the sildenafil, was initially developed as a vasodilator agent and employed in therapy of angina, however, by chance, it was discovered to act on the erectile dysfunction. Drugs like it are also used in pulmonary hypertension. Potential effects on the retina, heart and blood pressure were the targets of investigations (PACHE et al., 2002;

IDepartamento de Medicina Veterinária, Escola de Veterinária, Universidade Federal de Goiás (UFG), Jataí, GO, Brasil.

IIDepartamento de Clínica e Cirurgia Veterinária, Faculdade de Ciências Agrárias e Veterinárias (FCAV), Universidade Estadual de São Paulo (UNESP), Via de Acesso Prof. Paulo Donato Castellane S/N, 14884-900, Jaboticabal, SP, Brasil. E-mail: jllaus@fcav.unesp.br.

*Autor para correspondência.

IIIDepartamento de Medicina Veterinária, Faculdade de Medicina Veterinária e Zootecnia, UFG, Goiânia, GO, Brasil. Received 07.22.13 Approved 12.11.13 Returned by the author 07.09.14 CR-2013-0981.R2 
POLAK et al., 2003; AMERI et al., 2008; FORESTA et al., 2008; CORDELL et al., 2009).

Phosphodiesterase type 5 inhibitor drugs, originally developed as antiaginal, are able to inhibit the hydrolysis of cGMP in the corpus cavernosum, increasing the concentration of this second messenger in the smooth wall of vessels. The event results in increased intravascular action of nitric oxide (NO) and vasodilation on the site. Nevertheless, PDE5 inhibitors may also act by inhibiting the type- 6 phosphodiesterase (PDE-6) present in the retina, with complications to the vision (ASHBY, 2006). There is evidence that the sildenafil citrate increases retinal blood circulation and it is speculated that the event is a consequence of increased blood flow, per vasodilation, similar to what happens within the corpus cavernosum sphere (GRUNWALD et al., 2001; POLAK et al., 2003; FORESTA et al., 2008).

Identifying and quantifying some vasodilator activity on the retina, resulting from the action of the sildenafil citrate, would bring significant clinical benefits. When designing this research, the question was whether the sildenafil citrate could cause changes in the hemodynamics and perfusion of the retina.

\section{MATERIAL AND METHODS}

The effects of sildenafil were evaluated in 18 adult, male, albino, homozygote rabbits, of the New Zealand White breed, randomly divided into 3 groups of 6 animals, for drug treatment at a dose of $3.5 \mathrm{mg}$ $\mathrm{kg}^{-1}$ every 24 hours, for 7, 15 and 30 days, and in 9 control animals, totaling 27 subjects. For the selection of animals to compose the search, the Schirmer tear test (Schirmer tear test, Ophthalmos Ltda.), the biomicroscopy with slit-lamp (XL-1 Slitlamp ${ }^{\circledR}$, ShinNippon), the gonioscopy (Koe ppe medium diagnostic lens $\left.18 \mathrm{~mm}, \operatorname{Acular}^{\circledR}\right)$, the applanation tonometry (Tono Pen $\mathrm{XL}^{\circledR}$, Medtronic), the indirect binocular ophthalmoscopy (indirect binocular ophthalmoscope FOH- $5^{\circledR}$, Eyetec S.A.) and the proof of dyeing by fluorescein (Fluoresceína strips, Ophthalmos Ltda.) were performed as described by TALIERI et al. (2006).

After 24 hours of the initial procedures, which included the evaluation of the intraocular pressure (IOP), basal mean arterial pressure (MAP), ocular perfusion pressure (PPO), ultrasonography and fluorescein angiography, the treatment protocols were initiated with sildenafil or placebo. The $3.5 \mathrm{mg}$ $\mathrm{kg}^{-1}$ dose of sildenafil was employed at intervals of 24 hours, orally, for 7, 15 and 30 days. For the control group, $0.9 \%$ saline solution was employed, orally. One hour after the administration of sildenafil citrate, on the $7^{\text {th }}, 15^{\text {th }}$ and $30^{\text {th }}$ days, the IOP, MAP and PPO were evaluated and the ultrasonography and fluorescein angiography were performed. The evaluations were conducted always at the same time, beginning one hour after the treatments (sildenafil and placebo). The IOP was evaluated by using a Tono Pen electronic applanation tonometer (Tono Pen $\mathrm{XL}^{\circledR}$, Medtronic), five minutes after the instillation of $0.5 \%$ anesthetic proparacaine-based eye drop (Anestalcon ${ }^{\circledR}$, Alcon), kept refrigerated $\left(5^{\circ} \mathrm{C}\right)$. For the MAP evaluation, the central ear artery was cannulated. A 24G catheter was used (BD Angiocath), attached to the skin with a drop of polymethylcyanoacrylate adhesive (Super Bonder, Henkel Ltda.). A multiparameter monitor (Monitor Multiparamétrico DIXTAL, DX 2010) was used. For the PPO, the method described by KIEL \& HEUVEN (1995) was used, where: PPO=MAP-IOP.

For ultrasonography evaluation, equipment for ophthalmic ultrasonography (Ultrascan A/B, Alcon $^{\circledR}$ ) was employed, equipped with highfrequency sector transducer $(20 \mathrm{MHz})$ and the B-mode technique. The animals were contained manually and a thick layer of sterile acoustic gel was applied directly on the ocular surface, with the transducer positioned, being the position indication mark toward the side palpebral fissure. The external ophthalmic artery was identified by using its curvature as point of reference, and its diameter was evaluated three times. The mean of three evaluations was employed as the basis for analysis (GONÇALVES, 2005).

For fluorescein angiography, $2 \mathrm{mg} \mathrm{kg}^{-1}$ of midazolam (Dormonid ${ }^{\circledR}$, Roche) were used associated to 50mg $\mathrm{kg}^{-1}$ ketamine (Quetamina ${ }^{\circledR}$, Vetnil) intramuscularly (VIANA, 2007). With the animal under anesthesia and cardiorespiratory functions monitored, the procedures for fluorescein angiography were initiated. The marginal ear vein was cannulated by using a $24 \mathrm{G}$ catheter. The pupils were dilated by using $1 \%$ tropicamide drops (Tropicamide Colírio $^{\circledR}$, Alcon). The head was positioned manually. A retinographer equipped with the Angioimage software (TRC 50-DX, Topcon) was used. Eye fundus was photographed. A 10\% sodium fluorescein (Fluoresceína sódica $100 \mathrm{mg} \mathrm{ml}^{-1}$ injetável, Novartis) was applied, intravenously, in bolus, at a $10 \mathrm{mg} \mathrm{kg}^{-1}$ dose. Serial images were taken for the angiogram of the arterial, arteriovenous and venous stages.

The data were evaluated by using the Kolmogorov Smirnov test concerning normality. Analyses of variance for repeated measurements, followed by post hoc Bonferroni test, were employed in the comparison between the means. A $\mathrm{P}<0.05$ significance level was adopted. 


\section{RESULTS}

Concerning the IOP, no statistically significant differences were found $(\mathrm{P}=0.41)$. The basal IOP mean was $12 \pm 6.22 \mathrm{~mm} \mathrm{Hg}^{-1}$. At day 7 it was $8.66 \pm 0.81$, at day 15 it was $9.83 \pm 1.47$ and at day 30 it was $9.83 \pm 1.72 \mathrm{mmHg}$.

The MAP basal mean was $84.83 \pm 7.13 \mathrm{mmHg}$. At day 7, after administration of sildenafil it was $78.50 \pm 17.49$, at day 15 it was $73.33 \pm 11.72$ and at day 30 it was $66.00 \pm 21.57$, however, there was no statistically significant difference $(\mathrm{P}=0.12)$.

Notwithstanding the non-statistical significance $(\mathrm{P}=0.24)$, the $\mathrm{PPO}$ tended to decrease after treatment with sildenafil citrate at the 7,15 and 30 days. The basal mean was $72.83 \pm 12.85 \mathrm{mmHg}$. At day 7 it was $69.83 \pm 17.37 \mathrm{mmHg}$, at day 15 it was $65.50 \pm 11.96 \mathrm{mmHg}$ and at day 30 it was $56.16 \pm 21.11 \mathrm{mmHg}$.

Concerning the ultrasonography, the mean of the external ophthalmic artery diameter before (basal) treatment was $2.545 \mathrm{~mm}$, differing significantly $(\mathrm{P}=0.03)$ from the animals treated for 7 days, in which it was $2.865 \mathrm{~mm}$. Animals treated for 15 days also showed an increased external ophthalmic artery diameter, however no significant difference was found when the mean basal values compared to the post-treatment ones $(\mathrm{P}=0.11)$. In animals treated for 30 days, there was significant increase $(\mathrm{P}=0.01)$. The mean of the ophthalmic artery diameter was $2.90 \mathrm{~mm}$.

At the fluorescein angiography (Figure 1 and Figure 2), the arterial stage in the animals treated with sildenafil for 7 and 15 days started more quickly, when compared to the arterial stage prior to treatment, however, a significant difference $(\mathrm{P}=0.06)$ was not evident. The average time between the application of contrast and its onset in the retinal arteries, before treatment, was $5.00 \pm 1.09$ seconds. In animals treated for 7 days it was $4.00 \pm 1.26$ seconds and at day 15 it was $3.83 \pm 1.32$ seconds. The time for the beginning of the arterial stage in animals treated for 30 days was $5.33 \pm 0.51$, similarly to basal values. The average time for the onset of the arteriovenous stage before treatment was $6.83 \pm 1.16$ seconds. In animals treated with sildenafil for 7 days it was $5.33 \pm 1.21$ seconds, in the animals treated for 15 days it was $5.16 \pm 1.16$ seconds and in the animals treated for 30 days it was

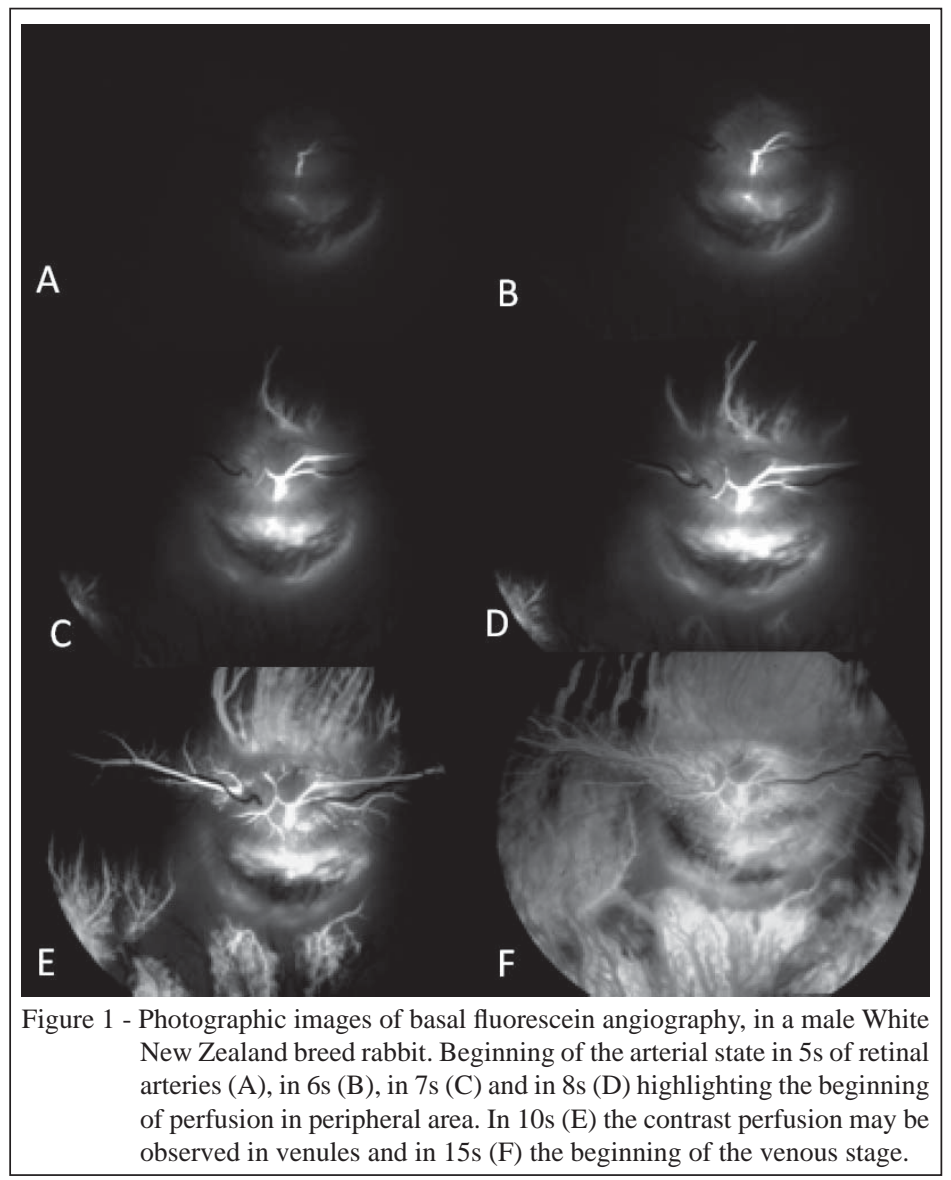

Ciência Rural, v.44, n.8, ago, 2014. 


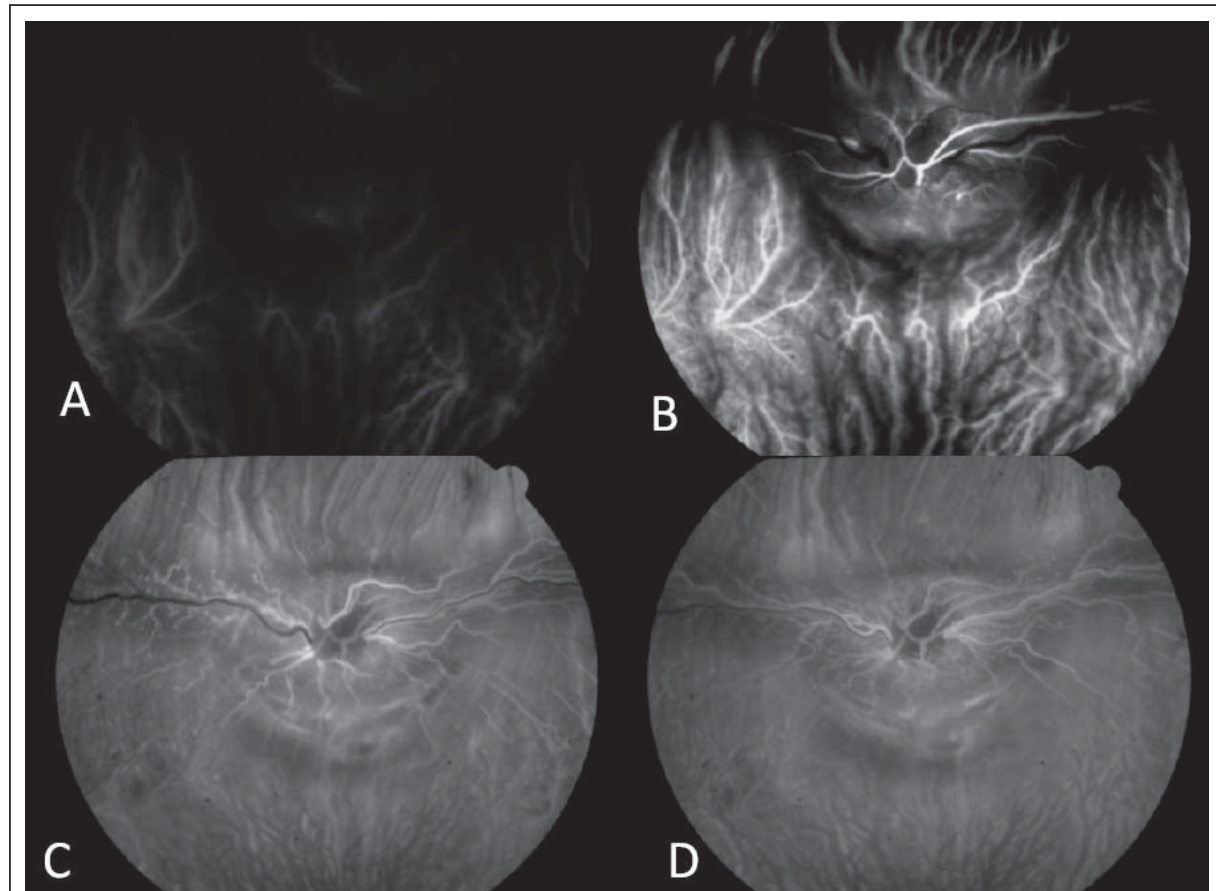

Figure 2 - Fluorescein angiography photographic images, 15 days after treatment with sildenafil citrate at a dose of $3.5 \mathrm{mgkg}^{-1}$ in a male New Zealand breed rabbit. Beginning of the arterial stage in $4 \mathrm{~s}$ diffusely in the retina (A), in 5s already showing perfusion in arteries and venules (arteriovenous stage) (B), in $6 \mathrm{~s}$ with beginning of the venous phase (C) and, at $11 \mathrm{~s}$ already showing reduced luminescence (D).

$6.33 \pm 0.49$ seconds. In animals treated for 15 days, the arteriovenous stage started more quickly than in other groups, presenting statistical significance $(\mathrm{P}=0.01)$. The venous stage in the animals treated with sildenafil for 7, 15 and 30 days started more quickly than in the untreated animals, however, statistical significance $(\mathrm{P}=0.13)$ was not found. The average time for the onset before treatment was $10.33 \pm 3.83$ seconds. In animals treated for 7 days it was $8.00 \pm 2.82$ seconds and in animals treated for 15 days it was $6.16 \pm 1.72$ seconds. In animals treated for 30 days, the average time for the beginning of the venous stage was $9.16 \pm 4.11$ seconds.

\section{DISCUSSION}

No significant changes concerning the IOP and the mean arterial pressure were found after treatments with sildenafil citrate. The results corroborate the ones presented by POLAK et al. (2003), which evaluated the same variables in men treated with a single dose of the drug. They do not differ from the ones presented by PACHE et al. (2002), which notified discrete decrease of the mean arterial pressure, with no evidences of heart or intraocular pressure changes. The IOP values found were kept according to the physiological values for rabbits (AMERI et al., 2008).

This research chose to study the ophthalmic artery and not the retinal central artery or the ciliary arteries for technical reasons. The ophthalmic artery was easily located at the ultrasonography, enabling the visibilization of anatomical ultrasonography standard feasible of repeatability. The consulted literature reports that the ophthalmic artery tends to be more sensitive to the vasodilator action of PDE5 inhibitors (GRUNWALD et al., 2001; PARIS et al., 2001; FORESTA et al., 2008).

Unlike reported by GRUNWALD et al. (2002), whose study showed no change in vascular caliber, the increased diameter of the ophthalmic artery, found in the present study, may have resulted from the inhibitory action of sildenafil citrate on PDE5 by continuous administration, which is also present in the arterioles of the corpus cavernosum penis, in the retina, in the lungs and in the coronary arteries. The PDE5 inhibition enhances the level of cGMP, intracellular messenger and nitric oxide, and mediates the vasodilation of arterioles in places such as the ones mentioned above (BENTLIN et al., 2005).

The fact that the intraocular pressure has not shown significant changes, despite the increased 
diameter of the external ophthalmic artery, it may be understood by the existence of intrinsic mechanisms of control of the intraocular pressure in that case. Blurred or momentary changes of the mean arterial pressure seem not to interfere in intraocular pressure (MAGGS, 2008). In this study, there were no significant changes in venous flow or in mean arterial pressure.

There was a PPO decrease in the animals treated with sildenafil citrate, but with no statistical significance. The event can be attributed to the ON increase by the drug, leading to vasodilation in the choroidal net, which would reduce the ocular perfusion pressure. The MAP decrease and the IOP decrease were summed to the PPO decrease. Despite the PPO decrease, increased speed of blood flow in the retina was observed, evidenced by the reduction of the onset time of the arterial, arteriovenous and venous stages.

It is known that the sildenafil citrate causes significant increase in the blood flow speed of the ophthalmic artery, dilation of theretina arteries and increase in the choroidal and retinal vessels flow (MCCULLEY et al., 2002; PACHE et al., 2002). The fluorescein angiography, however, had not been performed with such purpose, until this study was developed. SIU et al. (2000) evaluated the hemodynamic repercussion on ocular blood flow in patients who received $100 \mathrm{mg}$ of sildenafil. The laser Doppler flowmetry was used, but no significant changes were found.

There are few publications on fluorescein angiography in rabbits, and, in them, the description of the technique is slightly contemplated (AMERI et al., 2008; HELFENSTEIN et al., 2011). The $10 \mathrm{mg} \mathrm{kg}^{-1}$ dose of sodium fluorescein used, and the application technique, through the marginal ear vein, met the description by AMERI et al. (2008), almost fully.

For the arterial stage, the initial time of visibilization of fluorescence on retinal arteries or the choroidal filling was considered together with the presence of fluorescence in retinal arteries. The moment the dye was applied (SHIKANO \& SHIMIZU, 1969) was considered time zero. In some animals, the beginning of fluorescence happened in peripheral arteries, and not in the region of the optic nerve. The choroidal stage, oppositely to what is described for human patients, was not observed in this study.

For the arteriovenous stage, the complete filling of the retinal arterioles and venules was considered, as well as the presence of laminar flow in the veins, as proposed by GALÁN et al. (2006), for fluorescein angiography in sheep and goats. The authors mentioned that it was possible to identify the beginning of the arteriovenous stage when they visualize the contrast in venules close the optic disc.
For the venous stage, the presence of contrast was considered in all retinal veins, as well as throughout the choriocapillaris bed, keeping long term fluorescence (GALÁN et al., 2006).

In this study, the increased speed of blood flow in the retina was statistically significant, with decreased time to the onset of the arteriovenous stage at days $7^{\text {th }}$ and $15^{\text {th }}$ after treatment with sildenafil citrate, which agrees with the increased vascular flow in human choroid and retina, reported by POLAK et al. (2003) and HARRIS et al. (2008). The increase can be attributed to the dilation of retinal arterial vessels, by increased release of nitric oxide, through PDE5 inhibition (WRIGHT, 2006). Blood vessels are innervated by nitric oxide-producing neurons, which play an important role in local regulation of ocular blood flow, through the autonomic nervous system (GOLDSTEIN et al., 1996; TODA \& NAKANISHI-TODA, 2007).

The beginning of the venous stage decreased at day 15 of treatment with sildenafil citrate. The increased speed of blood flow, in the animals treated with sildenafil citrate, can be attributed to drug-generated retinal vasodilatation. The retinal vasodilatation, together with the decreased PPO and IOP, would be an excellent way to avoid the compensatory effects of chronic increase of IOP, as the retinal vasoconstriction example.

\section{CONCLUSION}

Based on the results obtained with the research, in the way it was designed, it is possible to admit that the sildenafil citrate improves blood circulation in the retina of rabbits, by increasing the speed of blood flow and decreasing the perfusion pressure.

\section{ACKNOWLEDGMENTS}

The autors thank Fundação de Amparo a Pesquisa ao Estado de São Paulo (FAPESP) ( $n^{\circ}$. 2010/00050-0) and Conselho Nacional de Desenvolvimento Científico e Tecnológico (CNPq) (n. 2010/300833-5) for grant support.

\section{ETHICS AND BIOSAFETY COMMITTEE}

The research was conducted meeting the standards of the Association for Research in Vision and Ophthalmology - ARVO (National Institutes of Health Publications Nr. 85-23: Revised 1985), according to the NUREMBERG code (GOLDIN JR, 1995). In addition, under the express permission of the Ethics Committee on the Use of Animals (protocol nr. 05637/10).

\section{REFERENCES}

AMERI,H.etal. Naturalcourseofexperimentalretinalveinocclusion in rabbit; arterial occlusion following venous photothrombosis. 
Archive for Clinical and Experimental Ophthalmology, v.246, p.1429-1439, 2008. Available from: <http://link.springer.com/art icle/10.1007\%2Fs00417-008-0878-4>. Accessed: Jun. 27, 2013. doi: 10.1007/s00417-008-0878-4

ASHBY, B. Prostaglandinas e autacóides correlatos. In: MINNEMAN, K.P.; WECKER, L. Brody - Farmacologia humana. Rio de Janeiro: Elsevier, 2006. p.211-216.

BENTLIN, M.R. et al. Sildenafil for pulmonary hypertension treatment after cardiac surgery. Journal of Pediatrics, v.81, n.2, p.175-178, 2005. Available from: <http://www.jped.com.br/ conteudo/05-81-02-175/ing.asp>. Accessed: Jun. 27, 2013.

CORDELL, W.H. et al. Retinal effects of 6 months of daily use of tadalafil or sildenafil. Archives of Ophthalmology, v.127, n.4, p.367-373, 2009. Available from: <http://archopht.jamanetwork. com/article.aspx?articleid=422745>. Accessed: Jun. 27, 2013. doi: 10.1001/archophthalmol.2009.36.

FORESTA, C. et al. Expression of the PDE5 enzyme on human retinal tissue: new aspects of PDE5 inhibitors ocular side effects. Eye, v.22, p.144-149, 2008. Available from: <http://www.nature. com/eye/journal/v22/n1/full/6702908a.html>. Accessed: Jun. 27, 2013. doi: 10.1038/sj.eye.6702908.

GALÁN, A. et al. Comparative fluorescein angiography of the normal sheep and gota ocular fundi. Veterinary Ophthalmology, v.9, n.1, p.7-15, 2006. Available from: <http://onlinelibrary.wiley. com/doi/10.1111/j.1463-5224.2005.00425.x/abstract>. Accessed: Jun. 27, 2013. doi: 10.1111/j.1463-5224.2005.00425.x.

GOLDIN JR. Pesquisa em saúde e direito dos animais. Porto Alegre: HCPA, 1995. 28p.

GOLDSTEIN, I.M. et al. Nitric oxide: a review of its role in retinal function and disease. Vision Research, v.36, p.2979-2994, 1996. Available from: <http://www.sciencedirect.com/science/ article/pii/004269899600017X $>$. Accessed: Jun. 27, 2012. doi: 10.1016/0042-6989(96)00017-X.

GONÇALVES, G.F. Pressão arterial média e fluxo sanguíneo da artéria oftálmica externa em gatos (Felis catus Linnaeus, 1758). 2005. 80f. Tese (Doutorado em Medicina Veterinária) Centro de Ciências Rurais, Universidade Federal de Santa Maria, Santa Maria, RS.

GRUNWALD, J.E. et al. Effect of sildenafil citrate (Viagra) on the ocular circulation. American Journal of Ophthalmology, v.131, p.751-755, 2001. Available from: <http://www.sciencedirect.com/ science/article/pii/S0002939400009442>. Accessed: Jun. 27, 2013. doi: 10.1016/S0002-9394(00)00944-2.

GRUNWALD L. et al. Effect of sildenafil citrate (Viagra) on retinal blood vessel diameter. American Journal of Ophthalmology, v.133, n.6, p.809-812, 2002. Available from: <http://www. sciencedirect.com/science/article/pii/S0002939402013910. Accessed: Sept. 17, 2013. doi: 10.1016/S0002-9394(02)01391-0.

HARRIS, A. et al. The effect of sildenafil on ocular blood flow. British Journal of Ophthalmology, v.92, n.4, p.469-473, 2008. Available from: <http://bjo.bmj.com/content/92/4/469.long>. Accessed: Sept. 17, 2013. doi: 10.1136/bjo.2007.131789.
HELFENSTEIN, T. et al. Impaired glucose tolerance plus hyperlipidaemia induced by diet promotes retina microaneurysms in New Zealand rabbits. International Journal of Experimental Pathology, v.92, p.40-49, 2011. Available from: <http:// onlinelibrary.wiley.com/doi/10.1111/j.1365-2613.2010.00753.x/ abstract>. Accessed: Jun. 27, 2013. doi: 10.1111/j.13652613.2010.00753.

POLAK, K. et al. Effects of sildenafil on retinal blood flow and flicker-induced retinal vasodilatation in healthy subjects. Investigative Ophthalmology \& Visual Science, v.44, n.11, p.4872-4876, 2003. Available from: <http://www.iovs.org/ content/44/11/4872.long>. Accessed: Jun. 27, 2013. doi: 10.1167/ iovs.03-0177.

KIEL, J.W.; HEUVEN, W.A.J. Ocular perfusion pressure and choroidal blood flow in the rabbit. Investigative Ophtalmology \& Visual Science, v.36, n.3, p.579-585, 1995. Available from: <http:// www.iovs.org/content/36/3/579.long>. Accessed: Jun. 27, 2013.

MAGGS, D.J. Basic diagnostic techniques. 4.ed. In: MAGGS, .DJ. et al. Slatter's Fundamentals of Veterinary Ophthalmology. Saunders: Philadelphia, 2008. p.81-106.

MCCULLEY, T. J. et al. Effects of sildenafil citrate (Viagra) on choroidal congestion. Ophthalmologica, v.216, p.455-458, 2002. Available from: <http://www.karger.com/Article/FullText/67549>. Accessed: Jun. 27, 2013. doi: 10.1159/000067549.

PACHE, M. et al. Sildenafil induces retinal vasodilatation in healthy subjects. British Journal of Ophthalmology, v.86, p.156158, 2002. Available from: <http://bjo.bmj.com/content/86/2/156. long>. Accessed: Jun. 27, 2013. doi: 10.1136/bjo.86.2.156.

PARIS, G. et al. Sildenafil increases ocular perfusion. International Ophthalmology, v.23, p.355-358, 2001.

SHIKANO, S.; SHIMIZU, K. Atlas of fluorescence fundus angiography. Tokyo: Igaku shoin, 1969. 201p.

SIU, K. et al. Effect of Viagra on ocular circulation. Investigative Ophthalmology \& Visual Science, v.41, p.98, 2000. Available from: <http://www.sciencedirect.com/science/ article/pii/S0002939400009442>. Accessed: Jun. 27, 2013. doi: 10.1016/S0002-9394(00)00944-2.

TALIERI, I.C. et al. Exame oftálmico em cães e gatos. Clínica Veterinária, n.61, p.42-54, 2006.

TODA, N.; NAKANISHI-TODA, M. Nitric oxide: ocular blood flow, glaucoma, and diabetic retinopathy. Progress in Retinal and Eye Research, v.26, p.205-238, 2007. Available from: <http:// www.sciencedirect.com/science/article/pii/S1350946207000055>. Accessed: Jun. 27, 2013. doi: 10.1016/j.preteyeres.2007.01.004.

VIANA, F.A.B. Guia terapêutico veterinário. 2.ed. Lagoa Santa: Cem, 2007. 444p.

WRIGHT, P.J. Comparison of phosphodiesterase type 5 (PDE5) inhibitors. International Journal of Clinical Practice, v.60, p.967-975, 2006. Available from: <http://onlinelibrary.wiley.com/ doi/10.1111/j.1742-1241.2006.01049.x/abstract>. Accessed: Jun. 27, 2013. doi: 10.1111/j.1742-1241.2006.01049.x. 